\title{
Diagonal earlobe creases and fatal cardiovascular disease: a necropsy study
}

\author{
N KIRKHAM, T MURRELLS, * D H MELCHER, E A MORRISON \\ From the Department of Pathology, Royal Sussex County Hospital, Brighton and the ${ }^{*}$ Epidemiology and \\ Public Health Research Unit, Robens Institute, University of Surrey, Guildford
}

SUMMARY The association between diagonal earlobe creases and fatal cardiovascular disease was investigated in a consecutive series of 303 coroner's necropsies. Those studied all died outside hospital in the Brighton Health District. Data were analysed on the cause of death and on the type of earlobe, the presence or absence of diagonal creases, age, sex, height, and any previous history of cardiovascular disease or diabetes mellitus. The age of nine men and six women was not known. Cardiovascular causes of death included ischaemic and hypertensive disease, calcific valvar stenosis, ruptured dissecting aneurysm of the thoracic aorta, and ruptured atheromatous aneurysm of the abdominal aorta. The mean (SD) age at death was $72(15)$ and the male to female ratio was 1.3:1. Diagonal creases were present in $123(72 \%)$ of 171 men and $88(67 \%)$ of 132 women. A previous history of cardiovascular disease was present in $90(30 \%)$ of the total of 303 and $74(35 \%)$ of the 211 with diagonal creases. A cardiovascular cause of death was present in $154(73 \%)$ of 211 with and $41(45 \%)$ of 92 without diagonal creases and was associated with an increased risk of a cardiovascular cause of death of 1.55 in men and 1.74 in non-diabetic women.

The Emperor Hadrian probably died of cardiovascular disease. Several busts, now in European museums, show quite distinct diagonal creases on both of his earlobes. ${ }^{1}$ Diagonal earlobe creases run from the lower pole of the external meatus, diagonally backwards to the edge of the lobe at approximately $45^{\circ}$ (figure), and have been associated with cardiovascular disease in several clinical studies. ${ }^{2-13}$ We studied a series of coroner's necropsy cases to see whether diagonal earlobe creases are associated with fatal cardiovascular disease.

\section{Patients and methods}

Data were collected from unselected consecutive necropsies conducted on behalf of HM Coroner on adults at the Brighton Borough Mortuary by three consultant pathologists. These people had died within the Brighton Health District in circumstances in which it was not possible to issue a death certificate. Before the pathologist arrived in the mortuary to perform the necropsy, at least two of the

Requests for reprints to Dr N Kirkham, Department of Pathology, Royal Sussex County Hospital, Brighton BN2 5BF.

Accepted for publication 19 January 1989 three members of the mortuary staff examined the ears. They classified the earlobe as soldered, attached, or free by comparing them with figure 1 in the paper by Overfield and Call. ${ }^{14}$ They used the definition of Brues: "The free lobe is attached only to the ear, not to the side of the face in front of and below the ear. The attached lobe blends into the back of the cheek; and soldered lobe is an extreme version of the attached form". ${ }^{15}$ The presence or absence of a diagonal crease on one or both ears was then recorded, together with details of age, sex, and height. The presence of a crease was only recorded if an unequivocal single crease was present, running diagonally backwards and downwards across the lobe from the external meatus. A photocopy of the figure in Frank's letter was used as a standard. ${ }^{2}$

After performing the necropsy the pathologist recorded the principal cause of death and classified it as cardiovascular or non-cardiovascular. This was done without taking the earlobe appearances into account. The presence or absence of a history of heart disease or diabetes mellitus was recorded from information supplied by the coroner's officers from their interviews with witnesses to the deaths and with the next of kin, which included details of all prescribed or proprietary medicines found in association with the subjects. 


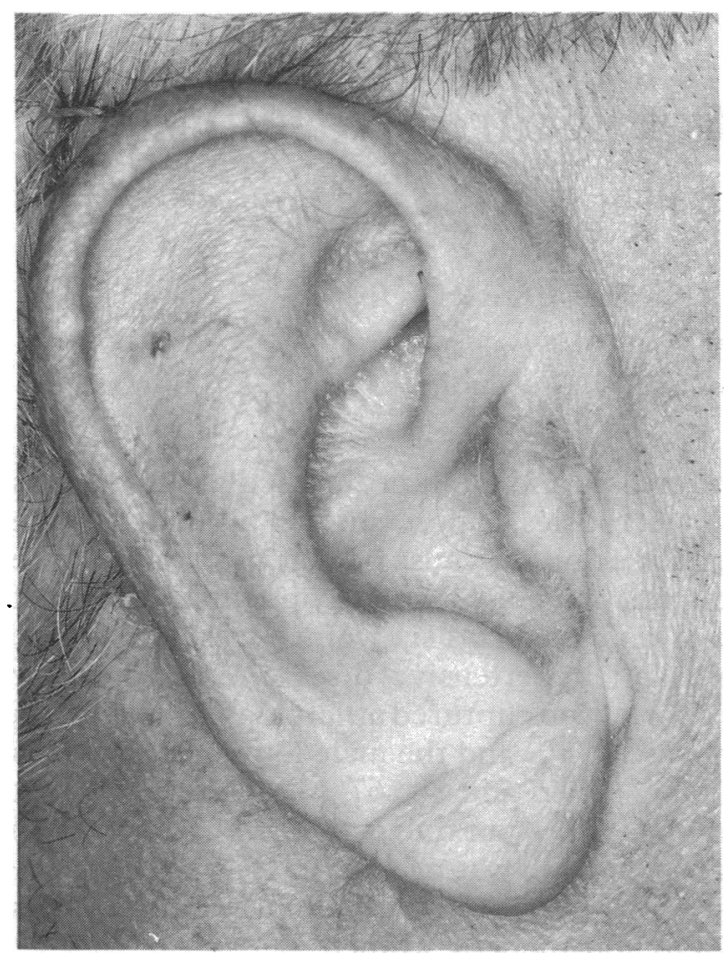

Fig Diagonal earlobe crease.

We investigated the relation between earlobe crease, age at death, height at death, diabetes, earlobe type, and the ratio of risks (RR) of cardiovascular cause of death, using the method proposed by Wacholder ${ }^{16}$ for the regression estimation of ratios of risk as defined by Armitage. ${ }^{17}$ These risk factors were fitted simultaneously into a regression model to identify those that were significantly related to the risk of cardiovascular cause of death while keeping the effects of all other risk factors constant. A model
Table 1 Earlobe type and diagonal creases

\begin{tabular}{lccr}
\hline Lobe type & Crease & No crease & All \\
\hline Soldered & 7 & 2 & 9 \\
Attached & 131 & 65 & 196 \\
Free & 73 & 25 & 98 \\
Total & 211 & 92 & 303 \\
\hline
\end{tabular}

that included the best predictors was chosen. We did not use odds ratios because approximations of relative risk when the proportion of subjects with cardiovascular disease is high tend to invalidate this approach.

\section{Results}

Data from 303 necropsies were collected. The age of 15 people was not known. The mean (SD) age of the group was $72 \cdot 2(14 \cdot 7)$. Details of age were available for 288 people: 162 men (mean (SD) age $70.3(12.8)$ and 126 women $(74.6(16 \cdot 6))$.

Most of the earlobes were of medium size and classified as attached; creases were slightly more common on the larger free type than on the attached type (table 1). The diagonal creases were easily recognised: the mortuary staff always agreed on whether they were present or absent. Creases were less common in those aged $\leqslant 55$. The frequency of creases remains fairly constant with increasing age in subjects from 55 years of age upwards (table 2). The proportion of creases at necropsies in those aged $\geqslant$ $55(191 / 260)$ was significantly higher than in the younger subjects $(11 / 28)(74 \% v 39 \%, p<0.001$, $95 \%$ confidence interval for the difference in proportions $17 \%$ to $52 \%$ ). The proportion of creases in males and females was similar $(123 / 171(72 \%) v 88 /$ $132(67 \%), 95 \%$ confidence interval for the difference in proportions $-5 \%$ to $16 \%$ ). A history of cardiovascular disease was present in 35\% (47/211)

Table 2 Number of people with a cardiovascular cause of death (total deaths in brackets) by age, sex, and presence or absence of a crease

\begin{tabular}{|c|c|c|c|c|c|c|}
\hline \multirow[b]{2}{*}{ Crease } & \multicolumn{5}{|l|}{ Age } & \multirow[b]{2}{*}{$A l l^{\star}$} \\
\hline & $<55$ & $55-64$ & $65-74$ & $75-84$ & $85+$ & \\
\hline $\begin{array}{l}\text { Men: } \\
\text { Present } \\
\text { Absent } \\
\text { RR } \\
(95 \% \mathrm{CI})\end{array}$ & $\begin{array}{l}5(7) \\
1(8) \\
5 \cdot 71 \\
(0 \cdot 86 \text { to } 37 \cdot 9)\end{array}$ & $\begin{array}{l}13(16) \\
6(8) \\
1.08 \\
(0.68 \text { to } 1.72)\end{array}$ & $\begin{array}{l}35(45) \\
11(14) \\
0.99 \\
(0.72 \text { to } 1 \cdot 36)\end{array}$ & $\begin{array}{l}34(39) \\
4(12) \\
2 \cdot 62 \\
(1 \cdot 16 \text { to } 5 \cdot 87)\end{array}$ & $\begin{array}{l}7(10) \\
3(3) \\
0.70 \\
(0.47 \text { to } 1.05)\end{array}$ & $\begin{array}{l}99(123) \\
26(48) \\
1.49 \\
(1.13 \text { to } 1.96)\end{array}$ \\
\hline $\begin{array}{l}\text { Women: } \\
\text { Present } \\
\text { Absent }\end{array}$ & $\begin{array}{l}0(4) \\
1(9)\end{array}$ & $\begin{array}{l}5(9) \\
0(1)\end{array}$ & $\begin{array}{c}10(13) \\
2(6)\end{array}$ & $\begin{array}{r}23(36) \\
7(15)\end{array}$ & $\begin{array}{r}15(23) \\
4(10)\end{array}$ & $\begin{array}{l}55(88) \\
15(44)\end{array}$ \\
\hline $\begin{array}{l}\text { RR } \\
(95 \% \mathrm{CI})\end{array}$ & $\begin{array}{r}3.85 \\
(0.53 \text { to }\end{array}$ & & $\begin{array}{l}2 \cdot 31 \\
(0.72 \text { to } 7 \cdot 44)\end{array}$ & $\begin{array}{l}1.37 \\
(0.76 \text { to } 2.48)\end{array}$ & $\begin{array}{l}1.63 \\
(0.72 \text { to } 3.69)\end{array}$ & $\begin{array}{l}1.83 \\
(1.18 \text { to } 2.85)\end{array}$ \\
\hline
\end{tabular}

*There was no record of the age of 15 people.

$\mathrm{CI}$, confidence interval; $R R$, ratio of risks. 
Table 3 Cardiovascular causes of death

\begin{tabular}{lr}
\hline Principal cause of death & No \\
\hline Ischaemic/hypertensive & 152 \\
Abdominal aneurysm & 15 \\
Thoracic aneurysm & 10 \\
Calcific aortic valve stenosis & 10 \\
Cor pulmonale & 6 \\
Cardiomyopathy & 2 \\
Total & 195 \\
\hline
\end{tabular}

of those with creases compared with $17 \%$ (16/92) of those without.

\section{CAUSES OF DEATH}

Cardiovascular causes of death were classified into six groups (table 3). Most deaths were the result of ischaemic and/or hypertensive disease. In addition, there were smaller groups with other principal cardiovascular causes of death; this may extend the number of possible cardiovascular conditions associated with diagonal earlobe creases.

In men, earlobe crease, diabetes, and height in those without a crease were predictive of cardiovascular death (table 4). For men of an average height at death of $175 \mathrm{~cm}$ the risk of a cardiovascular cause of death was $1.55(95 \%$ confidence interval $1 \cdot 15$ to $2 \cdot 10)$ times higher in those men with a crease than in those without a crease. Height was analysed as a continuous variable and did not appear to increase the risk of a cardiovascular cause of death in those men with a crease, but increasing height increased the risk in those without a crease. For women, age at death, diabetes, and creases in non-diabetics were predictive of a cardiovascular cause of death. Creases in diabetic women were not predictive. In non-diabetic women with an average age at death of 75 years the risk of cardiovascular cause of death was $1.74(95 \%$

Table 4 Log relative risk estimates from the "best" models for men and women

\begin{tabular}{|c|c|c|c|}
\hline & $\begin{array}{l}\text { Beta } \\
\text { (log relative } \\
\text { risk) }\end{array}$ & $\begin{array}{l}\text { Standard } \\
\text { error }\end{array}$ & $p$ \\
\hline \multicolumn{4}{|l|}{ Men: } \\
\hline $\begin{array}{l}\text { Crease } \\
\text { ^Height } \\
\text { Diabetes } \\
\text { Crease and height } \\
\text { interaction }\end{array}$ & $\begin{array}{r}0.441 \\
0.238 \\
0.212 \\
-0.249\end{array}$ & $\begin{array}{l}0.154 \\
0.054 \\
0.068 \\
0.066\end{array}$ & $\begin{array}{l}0.0042 \\
0.0001 \\
0.0018 \\
0.0002\end{array}$ \\
\hline \multicolumn{4}{|l|}{ Women: } \\
\hline $\begin{array}{l}\text { Crease } \\
\star \text { Age (linear) } \\
\star \text { Age (quadratic) } \\
\text { Diabetes } \\
\text { Crease and diabetes } \\
\text { interaction }\end{array}$ & $\begin{array}{r}0.551 \\
0.224 \\
-0.294 \\
0.936 \\
-0.579\end{array}$ & $\begin{array}{l}0 \cdot 243 \\
0 \cdot 100 \\
0 \cdot 129 \\
0 \cdot 230 \\
0 \cdot 243\end{array}$ & $\begin{array}{l}0.023 \\
0.025 \\
0.022 \\
0.0001 \\
0.017\end{array}$ \\
\hline
\end{tabular}

^Height and age were standardised to have mean zero and SD of one, separately for men and women. confidence interval 1.08 to 2.79 ) times higher when a crease was present.

\section{Discussion}

In 1973 Frank drew attention to the association between diagonal earlobe creases and coronary heart disease. $^{2}$ The creases on his patients' ears were usually bilateral and were associated with an increased number of other risk factors for coronary heart disease and with premature onset of the disease. He concluded that the presence of creases was a particularly useful marker of cardiovascular disease in those aged $<60$, a finding subsequently confirmed by Gral and Thornburg. ${ }^{3}$

Other workers have shown that up to $90 \%$ of patients with creases undergoing coronary angiography have significant disease. ${ }^{4}$ The creases are not usually present in childhood but develop during life, are not associated with diabetes, and should be regarded as a coronary risk factor. ${ }^{5}$ They become more common with age, with the greatest increase in the fifth decade, ${ }^{67}$ and are associated with increased degrees of coronary artery sclerosis. ${ }^{5}$

Creases tend to develop with coronary heart disease. ${ }^{389}$ This close relation seems to be independent of age but may be associated with a previous history of myocardial infarction. The exceptions to this are "Oriental patients, native American Indian patients, and children with Beckwith's syndrome."10

The possibility of an underlying genetic factor has been considered. A threefold increase in HLA-B27 has been shown and an association with the $\mathrm{C} 3-\mathrm{F}$ atherosclerosis gene $e^{11}$ and chromosome $11^{1819}$ has been suggested.

In a study of Japanese and American men aged 54 70 creases were found in $30 \%$ of subjects and were associated with obesity and systemic hypertension. A relation between creases and obesity rather than between creases and coronary heart disease was inferred..$^{12}$ Others have not found an association with obesity or with smoking, raised serum cholesterol, decreased high density lipoproteins, or systemic hypertension. ${ }^{13}$

We found a strong association between earlobe creases and a cardiovascular cause of death in men and women after age, height, and diabetes had been controlled for. Earlobe creases did not seem to increase the risk of a cardiovascular cause of death in diabetic women. We were not able to study the effect of obesity, but we saw as many creases on thin as fat people. The excess of elderly subjects reflects the fact that this was a group of people who had died suddenly and unexpectedly while living in the community. Although some may have been receiving treatment as hospital inpatients, none was in hospital 
at the time of death. In addition to coronary heart disease, we found that those with other fatal cardiovascular diseases such as ruptured aortic aneurysms also tended to have earlobe creases.

The presence of the combination of a previous history of cardiovascular disease and earlobe creases was not as strongly associated with cardiovascular causes of death as the presence of an earlobe crease alone. This suggests that cardiovascular disease was being underdiagnosed in this population. We conclude that diagonal earlobe creases are associated with cardiovascular causes of death.

We thank the staff of the Brighton Borough Mortuary for their help in collecting the data for this study.

\section{References}

1 Petrakis NL. Diagonal earlobe creases, type A behaviour and the death of Emperor Hadrian. West $J$ Med 1980;132:87-91.

2 Frank ST. Aural sign of coronary-artery disease. $N$ Engl J Med 1973;289:327-8.

3 Gral T, Thornburg M. Earlobe creases in a cohort of elderly veterans. J Am Geriatr Soc 1983;31:134-6.

4 Sternlieb JJ, Gau TG, Davis GD, Rutherford BD, Frye RL. The ear crease sign in coronary artery disease. Circulation 1974;suppl III:152.

5 Lichstein E, Chapman I, Gupta PK, et al. Diagonal earlobe crease and coronary artery sclerosis. Ann Intern Med 1976;85:337-8.

6 Mehta J, Hamby RI. Diagonal ear-lobe creases as a coronary risk factor. $N$ Engl J Med 1974;291:260.

7 Christiansen JS, Mathiesen B, Andersen AR, Calberg $\mathrm{H}$. Diagonal ear-lobe crease in coronary heart disease. N Engl J Med 1975;293:308-9.

8 Kaukola S. The diagonal ear-lobe crease, heredity and coronary heart disease. Acta Med Scand 1982;668(suppl):60-3.

9 Jorde LB, Williams RR, Hunt SC. Lack of association of diagonal earlobe creases with other cardiovascular risk factors. West $J$ Med 1984;140:220-3.

10 Elliott WJ. Ear lobe crease and coronary artery disease. 1,000 patients and review of the literature. Am J Med 1983;75:1024-32.

11 Kristensen BO. Ear-lobe crease and vascular complications in essential hypertension. Lancet 1980;i:265.

12 Rhoads GG, Klein K, Yano K, Preston H. The earlobe crease-sign of obesity in middle-aged Japanese men. Hawaii Med J 1977;36:74-7.

13 Kaukola S, Manninen V, Valle M, Halonen PI. Earlobe crease and coronary atherosclerosis. Lancet 1979;ii:1377.

14 Overfield T, Call EB. Earlobe type, race, and age: effects on earlobe creasing. Am J Geriatr Soc 1983;31: 479-81.

15 Brues AM. People and races. New York: Macmillan, 1977:118.

16 Wacholder S. Binomial regression in GLIM: estimating risk ratios and risk differences. Am J Epidemiol 1986;123:174-84.

17 Armitage P. Statistical methods in medical research. Oxford: Blackwell Scientific Publications, 1971: 426-33.

18 Jarrett RJ. Atherosclerosis, the earlobe crease, and chromosome II. Lancet 1984;i:513.

19 Dang CV. The earlobe crease: chromosomes, acupuncture, and atherosclerosis. Lancet 1984;i:1083. 